\title{
Current Progress in the Development of Zika Virus Vaccines
}

\author{
Kehui Zhou ${ }^{1,+}$, Chaoqun $\mathrm{Li}^{1,+}{ }^{+}$, Wen Shi ${ }^{1}$, Xiaodan $\mathrm{Hu}^{1}{ }^{1}$, Kutty Selva Nandakumar ${ }^{2, *(\mathbb{D}, \text { Shibo Jiang }}{ }^{3, *(\mathbb{D})}$ \\ and Naru Zhang $1, *$ (D) \\ 1 Department of Clinical Medicine, School of Medicine, Zhejiang University City College, \\ Hangzhou 310015, China; 31704257@stu.zucc.edu.cn (K.Z.); 31704246@stu.zucc.edu.cn (C.L.); \\ 31704195@stu.zucc.edu.cn (W.S.); 31704244@stu.zucc.edu.cn (X.H.) \\ 2 School of Pharmaceutical Sciences, Southern Medical University, Guangzhou 510515, China \\ 3 Key Laboratory of Medical Molecular Virology (MOE/NHC/CAMS), School of Basic Medical Sciences, \\ Shanghai Institute of Infectious Disease and Biosecurity, Fudan University, Shanghai 200032, China \\ * Correspondence: nandakumar@smu.edu.cn (K.S.N.); shibojiang@fudan.edu.cn (S.J.); \\ zhangnr@zucc.edu.cn (N.Z.) \\ + These authors contributed equally to this work.
}

Citation: Zhou, K.; Li, C.; Shi, W.; $\mathrm{Hu}$, X.; Nandakumar, K.S.; Jiang, S.; Zhang, N. Current Progress in the Development of Zika Virus Vaccines. Vaccines 2021, 9, 1004. https:// doi.org/10.3390/vaccines9091004

Academic Editor: Kevin Coombs

Received: 22 August 2021

Accepted: 7 September 2021

Published: 9 September 2021

Publisher's Note: MDPI stays neutral with regard to jurisdictional claims in published maps and institutional affiliations.

Copyright: (c) 2021 by the authors. Licensee MDPI, Basel, Switzerland. This article is an open access article distributed under the terms and conditions of the Creative Commons Attribution (CC BY) license (https:/ / creativecommons.org/licenses/by/ $4.0 /)$.

\begin{abstract}
Zika virus (ZIKV) is an arbovirus first discovered in the Americas. ZIKV infection is insidious based on its mild clinical symptoms observed after infection. In Brazil, after 2015, ZIKV infection broke out on a large scale, and many infected pregnant women gave birth to babies with microcephaly. The teratogenic effects of the virus on the fetus and its effects on nerves and the immune system have attracted great attention. Currently, no specific prophylactics or therapeutics are clinically available to treat ZIKV infection. Development of a safe and effective vaccine is essential to prevent the rise of any potential pandemic. In this review, we summarize the latest research on Zika vaccine development based on different strategies, including DNA vaccines, subunit vaccines, live-attenuated vaccines, virus-vector-based vaccines, inactivated vaccines, virus-like particles (VLPs), mRNA-based vaccines, and others. We anticipate that this review will facilitate further progress toward the development of effective and safe vaccines against ZIKV infection.
\end{abstract}

Keywords: Zika virus; vaccine; different strategies

\section{Introduction}

Zika virus (ZIKV) is a small envelope, positive-strand RNA virus belonging to the Flavivirus family of Flaviviridae [1]. As shown in Figure 1, the genome-encoded polyprotein can be cleaved into three structural proteins (capsid (C), anterior membrane (prM), and envelope (E)) and seven non-structural proteins (NS1, NS2A, NS2B, NS3, NS4A, NS4B, and NS5) [2]. The mature ZIKV particles consist of $90 \mathrm{E}$ homodimers and $90 \mathrm{M}$ homodimers on the lipid membrane, and the genomic RNA is surrounded by C protein (Figure 2). E proteins are responsible for receptor binding, attachment, viral entry, and membrane fusion. Transmission routes are arthropod vectors (e.g., Aedes aegypti), intrauterine (perinatal), and through sex and blood-related pathways [3]. ZIKV was also found to be present in the breast milk [4,5]. When ZIKV attacks pregnant women, it is easily reproduced in the placental tissue and seriously affects the fetal central nervous system and immune system, causing congenital Zika syndrome (CZS) in infants [6-8]. Studies have identified the major epitopes present on ZIKV structural proteins that can induce neutralizing antibodies [9]. Owing to high structural homology, the presence of common epitopes between Dengue virus (DENV) and ZIKV were reported earlier [10]. However, it is not feasible to prepare a ZIKV vaccine based on the principle of "cross-reactivity of the neutralizing antibodies" [11]. Several in vitro experiments demonstrated an antibody-dependent enhancement (ADE) of ZIKV infection after DENV infection, which poses a challenge to the development of a safe vaccine. In this review, we systematically discuss different types of Zika vaccines currently under development. 


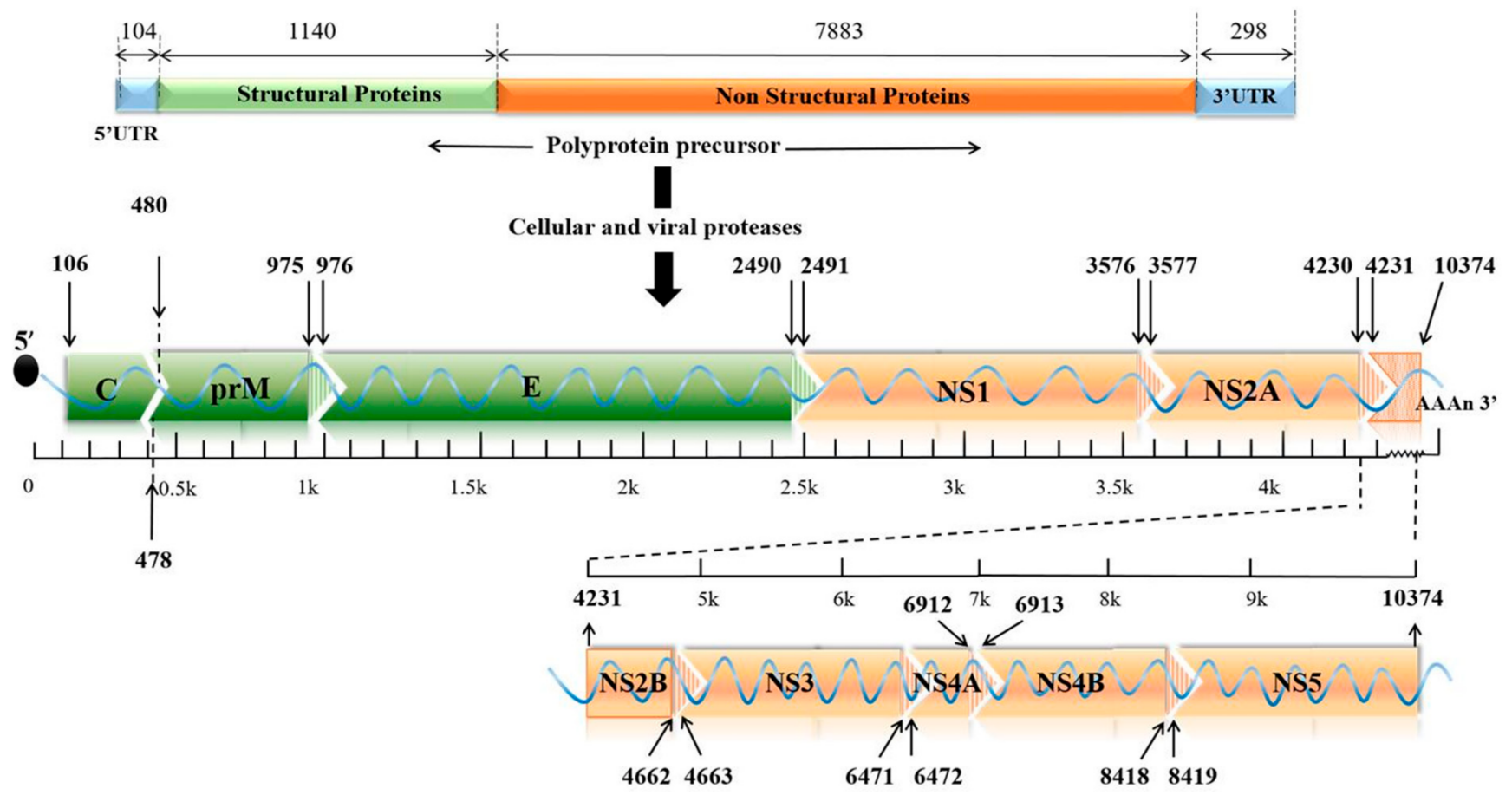

Figure 1. The genomic structure of ZIKV. The genome contains a single ORF encoding three structural proteins (C, prM, and E) and seven non-structural proteins (NS1, NS2A, NS2B, NS3, NS4A, NS4B, and NS5) with two UTRs at both ends. ORF: opening reading frame; C: capsid; prM: premembrane; E: envelope; UTR: untranslated region.

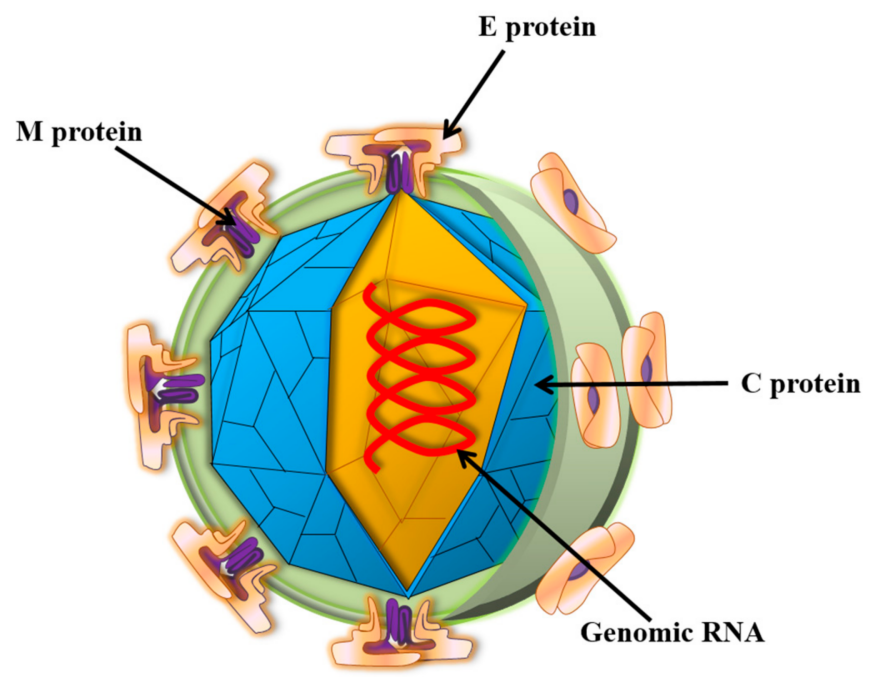

Figure 2. Schematic diagram of ZIKV structure. Zika virions are enveloped, spherical, and approximately $50 \mathrm{~nm}$ in diameter. The surface prM/M and E proteins are symmetrically arranged on the viral surface. M: membrane; E: envelope; C: capsid.

\section{Development of Vaccines against ZIKV Infection}

Development of a safe and an effective vaccine plays an important role in preventing the potential spread and serious harm caused by of ZIKV infection. Here we summarize and discuss different kinds of vaccines against ZIKV infection, including DNA vaccines, subunit vaccines, live-attenuated vaccines, virus-vector-based vaccines, inactivated vaccines, viruslike particle (VLP)- and mRNA-based vaccines. 


\subsection{DNA Vaccines against ZIKV Infection}

The DNA vaccine platform has been used for over twenty-five years to develop candidate vaccines against numerous pathogens. DNA vaccines can induce both humoral and cellular immune responses and are capable of mediating long-term protection [12]. Most currently developed DNA vaccines for ZIKV contain prM and E genes coding for prM and E proteins (Table 1). Type I interferon receptor alpha-chain null mice (Ifnar $1^{-/-}$mouse model) [13,14] exposed to ZIKV developed severe damage to the testes and sperm [15,16], but a DNA vaccine encoding ZIKV prM-E completely protected mice against such ZIKVassociated damage [17]. The immunogenicity of a DNA-based vaccine candidate, pVAX1ZME, expressing the prM/E protein of ZIKV, was evaluated in maternal and post-natal protection of suckling BALB/c mice, and it was demonstrated that the administration of three doses with $50 \mu \mathrm{g}$ of pVAX1-ZME by in vivo electroporation induced robust ZIKV-specific cellular and long-term humoral immune responses with high and sustained neutralizing activity in adult BALB/c mice. The neutralizing antibodies passively protected against ZIKV infection in neonatal mice and effectively inhibited delay in growth [18]. GLS-5700, a DNA-based vaccine that encodes the prM and $\mathrm{E}$ antigenic regions of ZIKV, was shown to prevent fertility loss in male IFNAR ${ }^{-/-}$mice [19]. The Vaccine Research Center (VRC) of the National Institute of Allergy and Infectious Diseases (NIAID) and National Institutes of Health (NIH) in USA have developed two DNA vaccine candidates, named VRC5288 and VRC5283, and tested them in phase I clinical trials to assess their safety, tolerability, and immunogenicity in humans [20]. Another DNA vaccine was developed by using a single tetrafunctional amphiphilic block copolymer $(\mathrm{ABC})$ encoding the full sequence of prM-E, which induced a high neutralizing antibody titer against three divergent ZIKV isolates in six-week-old female C57BL/6C mice [21].

Three different ZIKV NS1 DNA vaccines (encoding wild-type NS1 (pVAX-NS1), secreted NS1 with a tissue plasminogen activator (TPA) leader sequence introduced upstream of the NS1 to ensure efficient secretion (pVAX-tpaNS1), or NS1 secreted as a heptamer by fusing to a chimeric version of the oligomerization domain from the chicken complement inhibitor C4b-binding protein, termed as IMX313P (pVAX-tpaNS1-IMX313P)) were evaluated in 6- to 8-week-old BALB/c and IFNAR ${ }^{-/-}$mice. Results showed that the NS1-specific antibody titers and $\mathrm{CD}^{+}$, as well as $\mathrm{CD}^{+}, \mathrm{T}$-cell responses induced by pVAX-tpaNS1 vaccination were significantly higher and stronger than those induced by pVAX-NS1 and pVAX-tpaNS1- IMX313P [22]. This study highlights the importance of NS1 as a target for protective Zika vaccines and reaffirms the notion that TPA-driven NS1 secretion determines the immunogenicity of ZIKV NS1 in a DNA vaccine. Such an NS1 DNA vaccine might offer an attractive alternative to envelope-based vaccines because DNA vaccines targeting the NS1 gene do not have the risk of inducing ADE in individuals living in areas endemic for DENV and other flaviviruses.

DNA vaccines offer optimization of the sequences of the encoding genes in a flexible manner and the ability to test multiple candidate antigens rapidly [23]. They are chemically stable and easy to produce, with no requirement for cold-chain storage, and they are also cost-effective to manufacture on a large scale [22,24]. However, DNA vaccines involve expression of multiple foreign genes and thus have the potential of integrating the exogenous gene into the host genome, leading to induction of host autoimmunity [25]. 
Table 1. DNA vaccines against ZIKV infection.

\begin{tabular}{|c|c|c|c|c|c|c|}
\hline $\begin{array}{l}\text { Vaccine's Name } \\
\text { or Component }\end{array}$ & $\begin{array}{l}\text { Immunogenicity in the } \\
\text { Induction of } \\
\text { Immune Responses }\end{array}$ & Animal Model & Vaccine Doses & $\begin{array}{c}\text { Administration } \\
\text { Route }\end{array}$ & $\begin{array}{c}\text { Virus } \\
\text { Challenged }\end{array}$ & Ref. \\
\hline prM and $\mathrm{E}$ & $\begin{array}{l}\text { Completely protected mice } \\
\text { against ZIKV-associated } \\
\text { damage to the testes and } \\
\text { sperm and prevented viral } \\
\text { persistence in the testes }\end{array}$ & $\begin{array}{l}\text { Type-I interferon } \\
\text { knockout mice }\end{array}$ & $\begin{array}{l}\text { Two doses at } \\
\text { two-week } \\
\text { interval }\end{array}$ & i.m. & $\begin{array}{l}\text { Puerto Rico Strain } \\
\text { PRVABC59 }\end{array}$ & [17] \\
\hline $\begin{array}{l}\text { pVAX1-ZME } \\
\text { (prM and E) }\end{array}$ & $\begin{array}{l}\text { Induced robust } \\
\text { ZIKV-specific cellular and } \\
\text { long-term humoral immune } \\
\text { responses with high and } \\
\text { sustained neutralizing } \\
\text { activity, which provided } \\
\text { passive protection against } \\
\text { ZIKV infection in } \\
\text { neonatal mice }\end{array}$ & BALB/c mice & $\begin{array}{c}\text { Three doses at } \\
\text { three-week } \\
\text { intervals }\end{array}$ & i.m. & $\begin{array}{l}\text { (SMGC-1 strain, } \\
\text { GenBank } \\
\text { accession number: } \\
\text { KX266255 }\end{array}$ & [18] \\
\hline $\begin{array}{l}\text { GLS-5700 } \\
\text { (prM and E) }\end{array}$ & $\begin{array}{l}\text { Prevented fertility loss in } \\
\text { male IFNAR }{ }^{-/-} \text {mice }\end{array}$ & $\begin{array}{l}\text { C57BL } / 6 \mathrm{~J} \text { mice } \\
\text { and } \\
\text { IFNAR }^{-/-} \text {mice }\end{array}$ & $\begin{array}{l}\text { Two doses at } \\
\text { two-week } \\
\text { interval }\end{array}$ & i.m. & $\begin{array}{l}\text { Puerto Rico Strain } \\
\text { PRVABC59 }\end{array}$ & [19] \\
\hline $\begin{array}{l}\text { VRC5288 and } \\
\text { VRC5283 }\end{array}$ & $\begin{array}{l}\text { Induced detectable T-cell } \\
\text { response and antibody } \\
\text { response with neutralization } \\
\text { activity. The } \\
\text { immunogenicity of } \\
\text { VRC5283 was better than } \\
\text { that of VRC5288. }\end{array}$ & Humans & $\begin{array}{l}\text { Single dose, two } \\
\text { and three doses }\end{array}$ & i.m & No & [20] \\
\hline prM and $\mathrm{E}$ & $\begin{array}{l}\text { Elicited protective responses } \\
\text { against multiple diverse } \\
\text { ZIKV isolates }\end{array}$ & C57BL/6c mice & $\begin{array}{l}\text { Four doses at } \\
\text { days } 0,24,42, \\
\text { and } 199\end{array}$ & i.m & $\begin{array}{l}\text { Puerto Rico Strain } \\
\text { PRVABC59 }\end{array}$ & [21] \\
\hline $\begin{array}{l}\text { pVAX-NS1, } \\
\text { pVAX-tpaNS1, } \\
\text { pVAX-tpaNS1- } \\
\text { IMX313P } \\
\text { (NS1) }\end{array}$ & $\begin{array}{l}\text { pVAX-tpaNS1 vaccination } \\
\text { induced significantly higher } \\
\text { NS1-specific antibody titers } \\
\text { and CD4 }{ }^{+} \text {, as well as CD8 } \\
\text { T-cell responses compared } \\
\text { to pVAX-NS1 and } \\
\text { pVAX-tpaNS1- IMX313P }\end{array}$ & $\begin{array}{l}\mathrm{BALB} / \mathrm{c} \text { and } \\
\text { IFNAR }^{-/-} \text {mice }\end{array}$ & $\begin{array}{l}\text { Three doses at } \\
\text { two-week } \\
\text { intervals }\end{array}$ & i.d. & ZIKVzkv2015 & [22] \\
\hline
\end{tabular}

Note: prM, anterior membrane; E, envelope; IFNAR ${ }^{-/-}$, type I IFN receptor-deficient; i.m., intramuscular injection; i.d., intradermal injection.

\subsection{Subunit Vaccines against ZIKV Infection}

Based on their rapid, stable, and consistent production capabilities, subunit vaccines are considered as effective tools to prevent virus infection. Subunit vaccines against ZIKV have been designed and tested in animal models (Table 2). Viral structural proteins, such as E protein and its domain III (EDIII), are attractive vaccine targets. The immunogenicity of a subunit vaccine candidate comprised of ZIKV E protein and two clinical adjuvants (Alum and CoVaccine $\mathrm{HT}^{\mathrm{TM}}$ ) was evaluated in Swiss Webster, BALB/c, and C57BL/6 mice [26]. These vaccine formulations induced robust IgG titers and high levels of neutralizing antibodies in all three mouse strains and protected them against viremia after ZIKV infection [26]. Another research team used a recombinant subunit platform consisting of antigens produced in Drosophila melanogaster S2 cells to develop two candidate formulations. The first formulation contained $25 \mu \mathrm{g}$ of ZIKV E which was adjuvanted with $10 \mathrm{mg}$ $\mathrm{Co}-$ Vaccine $\mathrm{HT}^{\mathrm{TM}}$, and the second formulation contained $50 \mu \mathrm{g}$ of ZIKV E protein with Alhydrogel ${ }^{\circledR} 85$ plus $1.2 \mathrm{mg}$ of elemental aluminum. High neutralizing antibody titers were induced in a non-human primate (NHP) viremia model, and passive transfer of the plasma from the macaques protected against viremia in ZIKV-infected BALB/c mice [27]. Based on this observation, another research team agreed that high anti-ZIKV titers protected against viremia, but they also suggested that low titers could provide an incremental degree of protection, albeit not sufficient to prevent viremia [26]. Purified EDIII from transformed 
Escherichia coli inclusions induced high titers of IgG and ZIKV neutralizing antibodies, which showed no evidence of ADE induction in C57BL/6 mice [28].

Table 2. Subunit vaccines against ZIKV infection.

\begin{tabular}{|c|c|c|c|c|c|c|}
\hline $\begin{array}{l}\text { Vaccine's Name } \\
\text { or Component }\end{array}$ & $\begin{array}{l}\text { Immunogenicity in the } \\
\text { Induction of } \\
\text { Immune Responses }\end{array}$ & Animal Model & Vaccine Doses & $\begin{array}{l}\text { Administration } \\
\text { Route }\end{array}$ & $\begin{array}{l}\text { Virus } \\
\text { Challenged }\end{array}$ & Ref. \\
\hline \multirow[t]{2}{*}{$\mathrm{E}$} & $\begin{array}{l}\text { Induced robust antigen } \\
\text { binding IgG titers and high } \\
\text { levels of neutralizing } \\
\text { antibodies in the mice, } \\
\text { which protected against } \\
\text { viremia after ZIKV infection }\end{array}$ & $\begin{array}{l}\text { Swiss Webster, } \\
\text { BALB/c, and } \\
\text { C57BL/6 mice }\end{array}$ & $\begin{array}{c}\text { Three doses at } \\
\text { three-week } \\
\text { intervals }\end{array}$ & i.m. & $\begin{array}{l}\text { Puerto Rico Strain } \\
\text { PRVABC59 }\end{array}$ & {$[26]$} \\
\hline & $\begin{array}{l}\text { Induced high neutralizing } \\
\text { antibody titers }\end{array}$ & $\begin{array}{l}\text { Cynomolgus } \\
\text { macaques and } \\
\text { BALB/c mice }\end{array}$ & $\begin{array}{c}\text { Three doses at } \\
\text { three-week } \\
\text { intervals }\end{array}$ & i.m. & $\begin{array}{l}\text { Puerto Rico Strain } \\
\text { PRVABC59 }\end{array}$ & [27] \\
\hline EDIII & $\begin{array}{l}\text { Induced high titer of IgG } \\
\text { and ZIKV-neutralizing } \\
\text { antibodies and showed no } \\
\text { evidence of ADE induction } \\
\text { in mouse serum }\end{array}$ & C57BL/6 mice & $\begin{array}{l}\text { Four doses at } \\
\text { three-week } \\
\text { intervals }\end{array}$ & s.c. & $\begin{array}{l}\text { Puerto Rico Strain } \\
\text { PRVABC59 }\end{array}$ & [28] \\
\hline $\begin{array}{l}\text { E90 (Consisting } \\
\text { of the first } 450 \\
\text { amino acids at the } \\
\text { N-terminal region } \\
\text { of E protein) }\end{array}$ & $\begin{array}{l}\text { Immunization of pregnant } \\
\text { mice with E90 protected the } \\
\text { developing brains of } \\
\text { offspring, both in utero and } \\
\text { in the neonatal period, from } \\
\text { subsequent ZIKV infection } \\
\text { and microcephaly. E90 } \\
\text { induced robust } \\
\text { ZIKV-specific humoral } \\
\text { responses in adult } \\
\text { BALB/c mice. }\end{array}$ & $\begin{array}{l}\text { ICR (CD-1 im- } \\
\text { munocompetent) } \\
\text { mice; BALB/c } \\
\text { mice }\end{array}$ & $\begin{array}{l}\text { Two doses at } \\
\text { two-week } \\
\text { interval }\end{array}$ & i.p. & $\begin{array}{l}\text { GZ01 and } \\
\text { FSS13025 strains }\end{array}$ & {$[29,30]$} \\
\hline $\begin{array}{l}\text { EDIII fragments } \\
\text { (E296-406; } \\
\text { E298-409; } \\
\text { E301-404) }\end{array}$ & $\begin{array}{l}\text { Induced sustained } \\
\text { broad-spectrum } \\
\text { neutralization antibodies } \\
\text { and passive transfer of the } \\
\text { E298-409-specific antibodies } \\
\text { prevented ZIKV infection in } \\
\text { newborns and immunocom- } \\
\text { promised adults. }\end{array}$ & $\begin{array}{l}\text { BALB/c mice and } \\
\text { A129 mice }\end{array}$ & $\begin{array}{l}\text { Five doses at days } \\
\begin{array}{c}0,21,42,210, \\
\text { and } 300\end{array}\end{array}$ & i.m. & $\begin{array}{l}\text { R103451 and } \\
\text { FLR strains }\end{array}$ & {$[31]$} \\
\hline
\end{tabular}

Note: i.m., intramuscular injection; s.c., subcutaneous injection; i.p., intraperitoneal injection.

A truncated subunit vaccine consisting of the first 450 amino acids at the N-terminal region of the ZIKV FSS13025 strain E protein (E90) was investigated in 7- to 8-week-old CD-1 (ICR) immunocompetent mice for both in utero and neonatal ZIKV infection. Results demonstrated that immunization of pregnant mice with E90 protected the developing brains of offspring, both in utero and during the neonatal period, from subsequent ZIKV infection and microcephaly. Most importantly, E90 vaccination protected mice from ZIKV infection, even at 140 days post-immunization [29]. Another group showed robust induction of ZIKV-specific humoral response in adult BALB/c mice by E90, and passive transfer of the antisera from these mice conferred absolute protection against lethal ZIKV challenge in a neonatal mouse model [30]. These studies demonstrated the promising nature of recombinant ZIKV E90 as a ZIKV subunit vaccine that deserves further clinical development. One study used seven-day-old male and female BALB/c pups, 6 to 8-week-old female BALB/c mice, and 5-week-old male and female type-I IFN receptor-deficient A129 mice to investigate the long-term immunogenicity and neutralizing activity of the ZIKV EDIII fragments. The results showed that ZIKV EDIII fragment, especially E298-409, could induce sustained development of neutralizing antibodies [31]. The E298-409-specific antibodies upon passive transfer prevented ZIKV infection in newborns and immunocompromised adults [31]. Thus, this subunit vaccine based on the critical fragment (E298-409) of ZIKV EDIII is one of the promising vaccine candidates for ZIKV infection. It has been proven that 
the recombinant ZIKV subunit vaccine is a safe and efficacious option for the prevention of ZIKV infection. However, its less immunogenic nature is the major disadvantage, requiring more doses and appropriate adjuvants [32].

\subsection{Live-Attenuated Vaccines against ZIKV Infection}

Live-attenuated vaccines (LAV) are those that reduce the infectivity of pathogens after various treatments, but retain their immunogenicity. A number of live-attenuated vaccines have been evaluated in animal models (Table 3). Candidate LAV viruses with engineered deletions in the $3^{\prime}$ untranslated region (UTR) provide immunity and protection in animal models of ZIKV infection [33]. Recently, a LAV candidate containing a 10-nucleotide deletion in the $3^{\prime}$ UTR of the ZIKV genome (10-del ZIKV) was developed. Even when immunized at a low dose with only 10-del ZIKV, complete protection from viremia by the induction of a high level of neutralizing antibodies was observed, preventing a decrease in the sperm count in A129 mice [34]. Another LAV candidate containing a 20-nucleotide deletion in the $3^{\prime}$ UTR of the ZIKV genome prevented viral transmission during pregnancy and testis damage in mice, as well as infection of NHP [35]. The ZIKV-3'UTR- $\Delta 20-\mathrm{LAV}$ is less sensitive to type-I-interferon inhibition than ZIKV-3'UTR- $\Delta 10-\mathrm{LAV}$ [34], making it more virulent than ZIKV-3' UTR- $\Delta 10-\mathrm{LAV}$ in A129 mice. Collectively, LAV candidates containing deletions in the $3^{\prime}$ UTR of the ZIKV genome are efficacious and have the potential to be promising vaccine candidates.

Table 3. Live-attenuated vaccines against ZIKV infection.

\begin{tabular}{|c|c|c|c|c|c|c|}
\hline $\begin{array}{l}\text { Vaccine's Name } \\
\text { or Component }\end{array}$ & $\begin{array}{l}\text { Immunogenicity in the } \\
\text { Induction of } \\
\text { Immune Responses }\end{array}$ & Animal Model & Vaccine Doses & $\begin{array}{c}\text { Administration } \\
\text { Route }\end{array}$ & $\begin{array}{l}\text { Virus } \\
\text { Challenged }\end{array}$ & Ref. \\
\hline $\begin{array}{c}\text { ZIKV-3' } \\
\text { UTR-10-LAV }\end{array}$ & $\begin{array}{l}\text { Showed complete protection } \\
\text { from viremia and induced a } \\
\text { saturated neutralizing } \\
\text { antibody response }\end{array}$ & A129 mice & Single dose & s.c. & $\begin{array}{l}\text { Cambodian strain } \\
\text { FSS13025 and } \\
\text { Puerto Rico strain } \\
\text { PRVABC59 }\end{array}$ & [34] \\
\hline $\begin{array}{c}\text { ZIKV-3' } \\
\text { UTR-20-LAV }\end{array}$ & $\begin{array}{l}\text { Induced strong immune } \\
\text { responses and protected } \\
\text { ZIKV-induced damage to } \\
\text { testes in mice; induced } \\
\text { sterilizing immunity in NHPs }\end{array}$ & $\begin{array}{l}\text { A129 mice and } \\
\text { rhesus macaques }\end{array}$ & Single dose & s.c. & $\begin{array}{l}\text { Cambodian strain } \\
\text { FSS13025 and } \\
\text { Puerto Rico strain } \\
\text { PRVABC59 }\end{array}$ & [35] \\
\hline $\begin{array}{l}\text { ZIKV-NS1-LAV } \\
\text { (NS1) }\end{array}$ & $\begin{array}{l}\text { Markedly diminished viral } \\
\text { RNA levels in maternal, } \\
\text { placental, and fetal tissues, } \\
\text { which resulted in protection } \\
\text { against placental damage and } \\
\text { fetal death }\end{array}$ & $\begin{array}{l}\text { A129 mice } \\
\text { andrhesus } \\
\text { macaques }\end{array}$ & Single dose & s.c. & $\begin{array}{c}\text { Puerto Rico strain } \\
\text { PRVABC59 }\end{array}$ & [36] \\
\hline $\begin{array}{l}\text { LAV (with } \\
\text { 9-amino-acid } \\
\text { deletion in the } \\
\text { C protein) }\end{array}$ & $\begin{array}{l}\text { Not only elicited protective } \\
\text { immunity that completely } \\
\text { prevented viremia, morbidity } \\
\text { and mortality, but also fully } \\
\text { prevented infection of } \\
\text { pregnant mice and } \\
\text { maternal-to-fetal transmission }\end{array}$ & A129 mice & Single dose & s.c. & $\begin{array}{c}\text { Puerto Rico strain } \\
\text { PRVABC59 }\end{array}$ & [37] \\
\hline
\end{tabular}

Note: s.c., subcutaneous injection.

A live-attenuated ZIKV vaccine candidate encoding NS1 protein, but without glycosylation (ZIKV-NS1-LAV), was demonstrated to markedly diminish viral RNA levels in maternal, placental, and fetal tissues, which resulted in protection against placental damage and fetal death [36]. A single-dose LAV candidate containing a 9-amino-acid deletion in the viral capsid protein that infects cells with controlled, limited infection rounds was developed to test its safety and immunogenicity in A129 mice [37]. The results showed that a single-dose immunization of this LAV vaccine elicited protective immunity that completely prevented viremia, morbidity, and mortality. At the same time, it also fully prevented infection of pregnant mice and maternal-to-fetal transmission. Interestingly, 
injection of this vaccine with $10^{4}$ plaque-forming units to 1-day-old mice did not cause any disease or death, underscoring its safety [37].

The need for only a single dose, rapid onset of immune responses, and durable protection are the advantages of LAVs [24], but manufacture and transport of LAVs require cell-culture and cold-chain storage facilities, which are not often feasible in many countries. Combining the strengths of LAV and DNA vaccines may overcome these limitations. In this direction, a DNA-LAV was developed by engineering the cDNA copy of a ZIKV LAV genome into a DNA plasmid administered into A129 mice through the intramuscular route by using a clinically proven device, TriGrid ${ }^{\mathrm{TM}}$, to initiate the replication of LAVs [24]. A single-dose immunization with $0.5 \mu \mathrm{g}$ of the DNA-LAV vaccine elicited robust T-cell responses and production of high levels of neutralizing antibodies, which completely prevented testis infection, injury, and oligospermia in male mice [24]. This DNA-LAV vaccination also fully protected against ZIKV-induced disease and maternal-to-fetal transmission in pregnant mice [24]. Thus, the DNA-LAV approach is a promising platform for developing effective vaccines against ZIKV infection.

\subsection{Virus-Vector-Based Vaccines against ZIKV Infection}

Virus-vector-based vaccines of ZIKV are designed to introduce ZIKV genetic material into cells using a virus as the carrier to induce protective immunity and achieve lasting protection (Table 4). Lentivirus, retrovirus, and adeno-associated virus can be used as carriers. Adenovirus vectors (AAV) can reduce the risk of insertion mutagenesis, induce strong innate immune and adaptive immune responses in mammalian hosts, and are easy to use for genetic modifications [38]. Thus, AAVs are widely used in the treatment of infectious diseases. Adenovirus-vectored vaccines represent a favorable controlling strategy for the ZIKV epidemic. Two adenovirus-vectored Zika vaccines were constructed by inserting a ZIKV prM-E gene expression cassette into human adenovirus type 4 (Ad4prM-E) and 5 (Ad5-prM-E) vectors [39]. A replication-defective vector which contains the full length of prM-E genes of ZIKV PRVABC59 strain [39] was created. Surprisingly, ELISA and plaque reduction neutralization tests showed negligible levels of anti-ZIKV antibodies after Ad4-prM-E-vaccination in C57BL/ 6 mice, suggesting that Ad4-prM-E vaccination induces only T-cell responses, whereas Ad5-prM-E vaccination induced both anti-ZIKV antibody and T-cell response [39]. Interestingly, coadministration of UV-inactivated Ad4 vector with Ad5-prM-E vaccine led to significant reduction in CTL and overall T-cell responses, compared to Ad5-prM-E alone [40], highlighting the differences in serotypespecific immunity induced by adenovirus vectors.

An intranasal Zika vaccine based on the replication-deficient hAd5 expressing ZIKV prM and $E$ proteins recognized by the human antibody repertoire was able to induce both cell-mediated and humoral immune responses, which conferred protection against ZIKV challenge as demonstrated in a preclinical model of ZIKV infection [41]. Two novel hAd5vector vaccines expressing ZIKV prM-E (Ad5-Sig-prM-Env) and E (Ad5-Env) proteins were constructed and evaluated in multiple non-lethal and lethal animal models using epidemic ZIKV strains [42]. Both vaccines elicited robust humoral and cellular immune responses in immunocompetent BALB/c and A129 mice, but Ad5-Sig-prM-Env-vaccinated mice had significantly higher ZIKV-specific neutralizing antibody titers and lower viral loads than Ad5-Env-vaccinated mice, suggesting that the Ad5-Sig-prM-Env vaccine was more immunogenic [42]. Four replication-deficient chimpanzee adenoviral (ChAdOx1) ZIKV vaccine candidates having addition or deletion of $\mathrm{prM}$ and $\mathrm{E}$, with or without its transmembrane domain (TM), were designed and evaluated in vivo [43]. A single dose of ChAdOx1 ZIKV vaccine, without adjuvant, induced protective responses in ZIKV-challenged BALB/c mice [43]. ChAdOx1 prME, encoding prM, but with TM deletion, conferred $100 \%$ protection with long-lasting anti-E immune response and no ADE to dengue virus infection [43]. On the other hand, deletion of prM and addition of TM reduced protective efficacy and yielded lower anti-E responses [43]. This study highlights the importance of rational design of viral-vectored ZIKV vaccines for best protective responses. A single-slot recombinant rhesus 
adenovirus serotype 52 (RhAd52) vector-based vaccine, expressing ZIKV prM and E, induced ZIKV-specific neutralizing antibody responses, as well as E-specific cellular immune responses in rhesus monkeys, conferring complete protection against ZIKV challenge [44]. The genetic structure of rhesus monkey adenoviruses resembles that of other human or chimpanzee adenoviruses; therefore, rhesus adenovirus vectors have the potential advantage to be used as a novel class of vaccine vectors [47]. An attenuated recombinant vesicular stomatitis virus (rVSV)-based vaccine expressing ZIKV prM-E-NS1 as a polyprotein was tested in BALB/c and A129 mouse models. This vector vaccine induced ZIKV-specific antibodies and T-cell responses that conferred partial protection against ZIKV infection [45]. In order to avoid ADE-related effects, a recombinant VSV-based vaccine carrying the ZIKV strain PRVABC59 capsid protein (VSV-Capsid) was generated, and the recombinant VSVZikaE260-425 virus expressing amino acids 260-425 of ZIKV EDIII was used as a parallel control [46]. Both VSV-Capsid and VSV-ZikaE260-425 vaccines induced strong ZIKV-specific humoral responses in immunized BALB/c mice, but VSV-Capsid immunization elicited significantly higher levels of IFN- $\gamma+\mathrm{CD}^{+}$and CD4 ${ }^{+}$T-cells compared to the VSV-ZikaE260425 vaccine, demonstrating that the VSV-Capsid vaccine conferred more effective protection upon ZIKV challenge [46]. This study provided insights into the importance of ZIKV capsid protein for further development of Zika vaccines.

Table 4. Virus-vector-based vaccines against ZIKV infection.

\begin{tabular}{|c|c|c|c|c|c|c|}
\hline $\begin{array}{l}\text { Vaccine's Name or } \\
\text { Component }\end{array}$ & $\begin{array}{l}\text { Immunogenicity in the } \\
\text { Induction of } \\
\text { Immune Responses }\end{array}$ & Animal Model & Vaccine Doses & $\begin{array}{l}\text { Administration } \\
\text { Route }\end{array}$ & $\begin{array}{l}\text { Virus } \\
\text { Challenged }\end{array}$ & Ref. \\
\hline $\begin{array}{l}\text { Ad4-prM-E and } \\
\text { Ad5-prM-E }\end{array}$ & $\begin{array}{l}\text { Ad5-prM-E vaccination } \\
\text { induced both humoral and } \\
\text { T-cell responses, while } \\
\text { Ad4-prM-E induced only a } \\
\text { T-cell response. }\end{array}$ & C57BL/6 mice & $\begin{array}{l}\text { Two doses at } \\
\text { three-week } \\
\text { interval }\end{array}$ & i.m. & $\begin{array}{c}\text { Puerto Rico strain } \\
\text { PRVABC59 }\end{array}$ & [39] \\
\hline hAd5-prM-E & $\begin{array}{l}\text { Induced both cell-mediated } \\
\text { and humoral immune } \\
\text { responses, which conferred } \\
\text { protection against a } \\
\text { ZIKV challenge }\end{array}$ & $\begin{array}{l}\text { C57BL } / 6 \text { mice } \\
\text { and } \\
\text { Ifnar } 1^{-/-} \text {mice }\end{array}$ & Single dose & i.n. & $\begin{array}{c}\text { Puerto Rico strain } \\
\text { PRVABC59 }\end{array}$ & [41] \\
\hline $\begin{array}{l}\text { Ad5-Sig-prM-Env } \\
\text { (prM-E) and } \\
\text { Ad5-Env (E) }\end{array}$ & $\begin{array}{c}\text { Both vaccines elicited robust } \\
\text { humoral and cellular immune } \\
\text { responses in } \\
\text { immunocompetent BALB/c } \\
\text { mice, as well as in A129 mice, } \\
\text { but } \\
\text { Ad5-Sig-prM-Env-vaccinated } \\
\text { mice resulted in significantly } \\
\text { higher ZIKV-specific } \\
\text { neutralizing antibody titers } \\
\text { and lower viral loads than } \\
\text { Ad5-Env-vaccinated mice. }\end{array}$ & $\begin{array}{l}\text { BALB / c mice and } \\
\text { A129 mice }\end{array}$ & Single dose & i.m. & $\begin{array}{l}\text { Puerto Rico strain } \\
\text { PRVABC59 }\end{array}$ & [42] \\
\hline ChAdOx1 & $\begin{array}{l}\text { Induced high levels of } \\
\text { protective responses in } \\
\text { challenged mice }\end{array}$ & BALB/c mice & Single dose & i.m. & Brazilian ZIKV & [43] \\
\hline RhAd52-prMEnv & $\begin{array}{l}\text { Induced ZIKV-specific } \\
\text { neutralizing antibodies in } \\
\text { rhesus monkeys; antibodies } \\
\text { sufficient for protection } \\
\text { against ZIKV challenge } \\
\text { in mice }\end{array}$ & $\begin{array}{l}\text { Rhesus monkeys } \\
\text { and BALB/c mice }\end{array}$ & Single dose & i.m. & $\begin{array}{c}\text { Brazilian ZIKV } \\
\text { and Puerto Rico } \\
\text { strain PRVABC59 }\end{array}$ & {$[44]$} \\
\hline
\end{tabular}


Table 4. Conts.

\begin{tabular}{|c|c|c|c|c|c|c|}
\hline $\begin{array}{l}\text { Vaccine's Name or } \\
\text { Component }\end{array}$ & $\begin{array}{l}\text { Immunogenicity in the } \\
\text { Induction of } \\
\text { Immune Responses }\end{array}$ & Animal Model & Vaccine Doses & $\begin{array}{c}\text { Administration } \\
\text { Route }\end{array}$ & $\begin{array}{c}\text { Virus } \\
\text { Challenged }\end{array}$ & Ref. \\
\hline rVSV-prM-E-NS1 & $\begin{array}{l}\text { Induced ZIKV-specific } \\
\text { antibody and T-cell immune } \\
\text { responses that conferred } \\
\text { partial protection against } \\
\text { ZIKV infection }\end{array}$ & $\begin{array}{l}\text { A129 mice and } \\
\mathrm{BALB} / \mathrm{c} \text { mice }\end{array}$ & Single dose & i.n. & $\begin{array}{c}\text { Cambodian strain } \\
\text { FSS13025 }\end{array}$ & [45] \\
\hline $\begin{array}{l}\text { VSV-Capsid and } \\
\text { VSV-ZikaE260-425 }\end{array}$ & $\begin{array}{l}\text { Both vaccines induced strong } \\
\text { ZIKV-specific humoral } \\
\text { responses in immunized } \\
\text { BALB/c mice, but } \\
\text { VSV-Capsid immunization } \\
\text { elicited significantly higher } \\
\text { levels of IFN- } \gamma+\text { CD } 8^{+} \text {and } \\
\text { CD4 } 4^{+} \text {T-cells than that of } \\
\text { VSV-ZikaE260- } 425 \text { vaccine. }\end{array}$ & BALB/c mice & Single dose & i.n. & $\begin{array}{l}\text { Puerto Rico strain } \\
\text { PRVABC59 }\end{array}$ & [46] \\
\hline
\end{tabular}

Note: i.m., intramuscular injection; i.n., intranasal injection.

The virus-vector-based Zika vaccines have high efficiency in inducing a faster immune response. However, some vectors have pre-existing immunity in human, which significantly prevents their use in the development of promising vaccine candidates. For example, humans have neutralizing antibodies against AAV vectors $[48,49]$ that prevent readministration of these vectors [50], thus causing limitations in using this type of gene therapeutic strategy. Tolerogenic rapamycin nanoparticles were used to induce immunosuppression to overcome the anti-AAV antibody issue, but they were not efficient in removing these antibodies [51]. The gram-positive Streptococcus pyogenes bacterium is a common human pathogen, which secretes IgG-degrading cysteine endopeptidase (called IdeS or imlifidase), which cleaves circulating IgG with a unique specificity $[52,53]$ and is therefore useful in the treatment of several diseases [54-56]. Recently, IdeS treatment was shown to overcome the issue of pre-existing anti-AAV neutralizing antibodies, thus further enabling gene therapy [57].

\subsection{Purified Inactivated Zika Vaccines (PIZV)}

The inactivated virus vaccine is produced by killing the original live virus through heat or chemicals and then introducing the remaining virus shell into the host body. Different inactivation strategies are used, such as UV, formalin and iodonaphthyl azide. It was reported that 50 and $100 \mu \mathrm{M}$ of iodonaphthyl azide could completely inactivate ZIKV [58]. A number of PIZV candidates have been evaluated in animal models (Table 5).

Two-dose immunization of alum/adjuvant-added, purified, inactivated ZIKV vaccine (PIZV) protected AG129 mice against lethal ZIKV challenge [59]. In addition, passive immunization of naïve mice with anti-ZIKV-immune serum showed a strong positive correlation between neutralization antibody titers and protection against lethal challenge with ZIKV [59]. PIZV with aluminum hydroxide, developed by the Walter Reed Army Institute of Research and further optimized by Sanofi Pasteur, induced robust neutralizing antibody responses and provided absolute protection from challenge with a homologous ZIKV strain in immunocompetent BALB/c mice and in Cynomolgus macaques [60,61]. Two-dose vaccination of PIZV at varying concentrations, ranging from $0.016 \mu \mathrm{g}$ to $10 \mu \mathrm{g}$, elicited a dose-dependent and long-lasting neutralizing antibody response in Indian rhesus macaques [62]. Complete protection against ZIKV infection was achieved with the higher PIZV doses of $0.4 \mu \mathrm{g}, 2 \mu \mathrm{g}$, and $10 \mu \mathrm{g}$ at 6 weeks and with $10 \mu \mathrm{g}$ PIZV at 1-year postvaccination [62]. Two doses of PIZV gave robust protection against ZIKV challenge in rhesus monkeys at 1-year post-vaccination [63]. A single-dose vaccination of PIZV in a dengue virus (DENV)-experienced human induced potent cross-neutralizing antibodies to both ZIKV and DENV [65]. The safety and immunogenicity of a PIZV vaccine candidate was evaluated in a double-blind, randomized, placebo-controlled phase I trial and shown to be safe and well tolerated in humans up to 52 weeks of follow-up. However, for the 
induction of PIZV immunogenicity, two doses were needed and, thus, not found to be durable [64]. An infectious cDNA clone of the clinical trial purified inactivated vaccine (PIV) strain PRVABC59 containing three viral replication-enhancing mutations (NS1 K265E, prM H83R, and NS3 S356F) produced more than 25-fold ZIKV than the wild type on Vero cells [66], suggesting that the cDNA clone-based manufacture platform has the advantage of higher virus yield, shortened manufacture time, and minimized chance for contamination.

Table 5. Inactivated vaccines against ZIKV infection.

\begin{tabular}{|c|c|c|c|c|c|c|}
\hline $\begin{array}{l}\text { Vaccine's Name } \\
\text { or Component }\end{array}$ & $\begin{array}{l}\text { Immunogenicity in the } \\
\text { Induction of } \\
\text { Immune responses }\end{array}$ & Animal Model & Vaccine Doses & $\begin{array}{c}\text { Administration } \\
\text { Route }\end{array}$ & $\begin{array}{c}\text { Virus } \\
\text { Challenged }\end{array}$ & Ref. \\
\hline \multirow[t]{2}{*}{$\begin{array}{l}\text { Alum-adjuvant } \\
\text { mixed purified } \\
\text { inactivated ZIKV } \\
\text { vaccine (PIZV) }\end{array}$} & $\begin{array}{l}\text { Two-dose vaccination of the } \\
\text { candidates was highly } \\
\text { immunogenic in the mouse } \\
\text { models, which protected } \\
\text { AG129 mice against lethal } \\
\text { ZIKV challenge. Passive } \\
\text { transfer of naïve mice with } \\
\text { ZIKV-immune serum also } \\
\text { showed full protection } \\
\text { against lethal } \\
\text { ZIKV challenge. }\end{array}$ & $\begin{array}{l}\text { CD-1 and AG129 } \\
\text { mice }\end{array}$ & $\begin{array}{l}\text { Three doses at } \\
\text { four-week } \\
\text { intervals }\end{array}$ & i.m. & $\begin{array}{c}\text { Puerto Rico strain } \\
\text { PRVABC59 }\end{array}$ & [59] \\
\hline & $\begin{array}{l}\text { Induced robust neutralizing } \\
\text { antibody responses and } \\
\text { provided complete } \\
\text { protection from homologous } \\
\text { ZIKV strain challenge }\end{array}$ & $\begin{array}{l}\text { BALB / c mice and } \\
\text { cynomolgus } \\
\text { macaques }\end{array}$ & $\begin{array}{c}\text { Two doses at } \\
\text { three/four-week } \\
\text { interval }\end{array}$ & i.m. & $\begin{array}{l}\text { Puerto Rico strain } \\
\text { PRVABC59 }\end{array}$ & {$[60,61]$} \\
\hline \multirow{3}{*}{ PIZV } & $\begin{array}{c}\text { Elicited a dose-dependent } \\
\text { and long-lasting } \\
\text { neutralizing } \\
\text { antibody responses }\end{array}$ & $\begin{array}{l}\text { Indian rhesus } \\
\text { macaques }\end{array}$ & $\begin{array}{l}\text { Two doses at } \\
\text { four-week } \\
\text { interval }\end{array}$ & i.m. & $\begin{array}{c}\text { Puerto Rico strain } \\
\text { PRVABC59 }\end{array}$ & {$[62]$} \\
\hline & $\begin{array}{l}\text { Two dose-vaccination of the } \\
\text { Type of vaccine gave a } \\
\text { robust protection against } \\
\text { ZIKV challenge. }\end{array}$ & rhesus macaques & $\begin{array}{l}\text { Two doses at } \\
\text { four-week } \\
\text { interval }\end{array}$ & $\begin{array}{l}\text { s.c., } \\
\text { i.m. }\end{array}$ & Brazil ZKV2015 & [63] \\
\hline & $\begin{array}{l}\text { Safe and well tolerated in } \\
\text { humans up to } 52 \text { weeks of } \\
\text { follow-up; but two doses } \\
\text { not durable for } \\
\text { immunogenicity required }\end{array}$ & $\begin{array}{l}\text { Phase I } \\
\text { clinical trial }\end{array}$ & $\begin{array}{l}\text { Single dose and } \\
\text { two doses at } \\
\text { two/four-week } \\
\text { interval }\end{array}$ & i.m. & No & {$[64]$} \\
\hline
\end{tabular}

Note: i.m., intramuscular injection; s.c., subcutaneous injection.

\subsection{Virus-Like Particle (VLP)-Based Vaccines against ZIKV Infection}

Virus-like particles (VLPs) are noninfectious because they are empty shell structures having no viral genome. Many viral structural proteins have the ability to assemble automatically into VLPs. They can be produced in a variety of expression systems, such as suspension cultures of mammalian, yeast and insect cells. A number of VLP-based ZIKV vaccines have been tested in animal models (Table 6).

VLPs were successfully produced by co-expression of the ZIKV structural proteins C-prM-E together with a truncated form of the protease NS3Pro linked to its cofactor NS2B constituting the viral NS2B/NS3Pro protease complex [67]. Recent studies have demonstrated that co-expression of ZIKV C-prM-E and ZIKV NS2B/NS3 [67] or WNV NS2B/NS3 protease [68] has facilitated the cleavage of C and prM, thereby allowing more efficient production of VLPs. Negative staining studies revealed that both VLPs and real virus particles are similar in size, morphology, as well as surface appearance. Indeed, the major surface glycoprotein E of ZIKV is present on the VLP surface [67], and E protein is the major target for neutralizing antibodies [68]. A VLP-based ZIKV vaccine composed of the prM gene of ZIKV located downstream of the heterogenic signal sequence and the $\mathrm{E}$ protein gene was generated in transiently transfected HEK293 cells [69]. A passive transfer 
experiment was carried out in AG129 mice, and the results showed that the VLP candidate induced a robust protective antibody response [69]. ZIKV VLPs consisting of prM and E could be quickly and easily generated by a baculovirus-insect expression system, and the VLPs stimulated high levels of ZIKV-specific neutralizing antibody titers and strong T-cell responses in all immunized mice [70]. A VLP carrier based on the hepatitis B core antigen (HBcAg) displaying the ZIKV E DIII (HBcAg-zDIII) domain was produced from Nicotiana benthamiana plants. Two doses of this VLP administration elicited potent humoral and cellular immune responses, which correlated with protective immunity against multiple strains of ZIKV in C57BL/6 mice [71].

VLPs mimic the conformation of natural viruses by expressing one or more structural proteins and thus stimulate robust antibodies in vivo. Antigens are present in their native conformation, but VLPs, to their advantage, use no replication virus [32]. However, application of VLP-based vaccine candidates for clinical use needs further studies.

\section{7. mRNA-Based Vaccines against ZIKV Infection}

Synthetic messenger RNAs (mRNAs) have emerged as a versatile and highly effective vaccine platform for encoding viral antigens, and they are quite attractive because of their production rapidity and flexibility. Some mRNA-based vaccines against ZIKV infection have been developed and tested in animal models (Table 6). A self-replicating mRNA vaccine encoding the ZIKV prM-E was generated, and intradermal electroporation of as little as $1 \mu \mathrm{g}$ of this vaccine elicited potent humoral and cellular immune responses in both $\mathrm{BALB} / \mathrm{c}$ and IFNAR1 ${ }^{-/-}$C57BL/ 6 mice [72]. In the latter group of mice, it resulted in complete protection from ZIKV infection [72]. To avoid ADE, a modified prM-E mRNA vaccine was designed by encoding mutations, which destroyed the conserved fusion-loop epitope in the E protein. This variant conferred protective immunity in immunocompetent mice against ZIKV infection and diminished ADE, both in vitro and in vivo [73]. Intradermal immunization of a single dose with lipid-nanoparticle-encapsulated nucleoside-modified mRNA (mRNA-LNP) encoding the prM-E proteins of a strain from ZIKV outbreak in 2013 induced potent and durable protective responses in BALB/c and C57BL/ 6 mice, as well as in rhesus macaques (Macaca mulatta) [74]. Similarly, a lipid nanoparticle-encapsulated, modified mRNA vaccine encoding ZIKV prM and E genes showed protection against placental damage and fetal death [9]. The nucleoside-modified mRNA vaccine represents a novel and promising vaccine candidate in the fight against ZIKV infection.

Table 6. VLP- and mRNA-based vaccines against ZIKV infection.

\begin{tabular}{|c|c|c|c|c|c|c|}
\hline $\begin{array}{l}\text { Vaccine's Name or } \\
\text { Component }\end{array}$ & $\begin{array}{l}\text { Immunogenicity in the } \\
\text { Induction of } \\
\text { Immune Responses }\end{array}$ & Animal Model & Vaccine Doses & $\begin{array}{c}\text { Administration } \\
\text { Route }\end{array}$ & $\begin{array}{l}\text { Virus } \\
\text { Challenged }\end{array}$ & Ref. \\
\hline $\begin{array}{l}\text { prM and E (HEK293 } \\
\text { expression system) }\end{array}$ & $\begin{array}{l}\text { Induced a protective } \\
\text { antibody response }\end{array}$ & AG129 mice & $\begin{array}{c}\text { Two doses at day } \\
0 \text { and } 32\end{array}$ & i.m. & $\begin{array}{l}\text { Prototype Zika } \\
\text { Nica 2-16 strain }\end{array}$ & [69] \\
\hline $\begin{array}{c}\text { prM and E } \\
\text { (Baculovirus } \\
\text { expression system) }\end{array}$ & $\begin{array}{l}\text { Stimulated ZIKV-specific IgG } \\
\text { and neutralizing antibodies, } \\
\text { as well as T-cell responses }\end{array}$ & BALB/c mice & $\begin{array}{l}\text { Three doses at } \\
\text { two-week } \\
\text { intervals }\end{array}$ & i.m. & $\begin{array}{l}\text { ZIKV strain } \\
\text { SZ-WIV01 }\end{array}$ & [70] \\
\hline $\begin{array}{l}\text { EDIII (Nicotiana } \\
\text { benthamiana plant } \\
\text { expression system) }\end{array}$ & $\begin{array}{l}\text { Elicited potent humoral and } \\
\text { cellular immune responses } \\
\text { correlated with protective } \\
\text { immunity against } \\
\text { multiple strains }\end{array}$ & C57BL/ 6 mice & $\begin{array}{c}\text { Three doses at } \\
\text { three-week } \\
\text { intervals }\end{array}$ & s.c. & $\begin{array}{l}\text { Puerto Rico } \\
\text { strain } \\
\text { PRVABC59 }\end{array}$ & [71] \\
\hline
\end{tabular}


Table 6. Conts.

\begin{tabular}{|c|c|c|c|c|c|c|}
\hline $\begin{array}{c}\text { Vaccine's Name or } \\
\text { Component }\end{array}$ & $\begin{array}{l}\text { Immunogenicity in the } \\
\text { Induction of } \\
\text { Immune Responses }\end{array}$ & Animal Model & Vaccine Doses & $\begin{array}{c}\text { Administration } \\
\text { Route }\end{array}$ & $\begin{array}{l}\text { Virus } \\
\text { Challenged }\end{array}$ & Ref. \\
\hline \multirow{3}{*}{ prM and $\mathrm{E}$} & $\begin{array}{l}\text { Intradermal electroporation of } \\
\text { as little as } 1 \mu \mathrm{g} \text { of this vaccine } \\
\text { elicited potent humoral and } \\
\text { cellular immune responses in } \\
\text { BALB/c and IFNAR }{ }^{-/-} \\
\text {C57BL/ } 6 \text { mice, resulting in } \\
\text { complete protection of the } \\
\text { latter mice against } \\
\text { ZIKV infection. }\end{array}$ & $\begin{array}{l}\mathrm{BALB} / \mathrm{c} \text { and } \\
\mathrm{IFNAR}^{-/-} \\
\text {C57BL } / 6 \text { mice }\end{array}$ & $\begin{array}{l}\text { Two doses at } \\
\text { four-week } \\
\text { interval }\end{array}$ & i.d. & $\begin{array}{l}\text { ZIKV strain } \\
\text { MR-766 }\end{array}$ & [72] \\
\hline & $\begin{array}{l}\text { Conferred protection and } \\
\text { sterilizing immunity in } \\
\text { immunocompetent mice } \\
\text { against ZIKV infection and } \\
\text { diminished ADE in vitro, as } \\
\text { well as in vivo }\end{array}$ & $\begin{array}{l}\text { AG129, BALB/c } \\
\text { and C57BL/6 } \\
\text { mice }\end{array}$ & $\begin{array}{l}\text { Single dose and } \\
\text { two doses at } \\
\text { three-week } \\
\text { interval }\end{array}$ & i.m. & $\begin{array}{l}\text { African ZIKV } \\
\text { strain } \\
\text { (Dakar 41519) }\end{array}$ & [73] \\
\hline & $\begin{array}{l}\text { Induced potent and durable } \\
\text { protective responses in mice } \\
\text { and non-human primates }\end{array}$ & $\begin{array}{l}\text { BALB /c and } \\
\text { C57BL/6 mice; } \\
\text { rhesus macaques } \\
\text { (Macaca mulatta) }\end{array}$ & Single dose & i.d. & $\begin{array}{l}\text { Puerto Rico } \\
\text { strain } \\
\text { PRVABC59 }\end{array}$ & [74] \\
\hline
\end{tabular}

Note: i.m., intramuscular injection; s.c., subcutaneous injection; i.d., intradermal injection.

\subsection{Other Types of Vaccines against ZIKV Infection}

Apart from the above-mentioned vaccine platforms, other types of vaccine candidates are also available against ZIKV. A chimeric ZIKV with DENV-2 prM-E genes was highly potent in A129 mice, and it induced robust neutralizing antibody responses, which conferred complete protection from challenge with ZIKV [75]. Over the last several years, computer-assisted peptide vaccines have started to draw much attention as alternative vaccine candidates. The peptide vaccine is a more focused approach to precisely locate the epitope region within the antigens and elicit immune responses. Occasionally, multiple peptides for one or more viral infections can be combined into clusters for immunization against a wide spectrum of infections [76].

The potential advantages and disadvantages of the above mentioned different types of vaccines are summarized in Table 7.

Table 7. Potential advantages and disadvantages of different types of Zika vaccines.

\begin{tabular}{|c|c|c|c|}
\hline Vaccine Types & Advantages & Disadvantages & Ref. \\
\hline DNA vaccines & $\begin{array}{l}\text { Chemically stable and cost effective; easy and } \\
\text { safe to scale up; can induce both humoral and } \\
\text { cellular immune responses and are capable of } \\
\text { mediating long-term protection }\end{array}$ & $\begin{array}{l}\text { Have the potential of integrating the } \\
\text { exogenous gene into the host genome, } \\
\text { leading to induction of host autoimmunity }\end{array}$ & {$[17-22,25]$} \\
\hline Subunit vaccines & Rapid, stable, and consistent production & $\begin{array}{l}\text { Normally need multiple doses with } \\
\text { appropriate adjuvants }\end{array}$ & {$[26-31]$} \\
\hline Live-attenuated vaccines & $\begin{array}{l}\text { Single dose could induce high immune } \\
\text { responses, rapid induction of } \\
\text { durable immunity }\end{array}$ & $\begin{array}{l}\text { Safety problems and need cold-chain } \\
\text { storage facilities }\end{array}$ & {$[24,34-37]$} \\
\hline Virus-vector-based vaccines & $\begin{array}{l}\text { Single dose could induce higher and faster } \\
\text { immune responses with lasting protection }\end{array}$ & Pre-existing immunity problem & {$[39,41-45,48,49]$} \\
\hline Inactivated vaccines & $\begin{array}{l}\text { Easy production and storage; convenient to } \\
\text { make multivalent vaccines }\end{array}$ & $\begin{array}{l}\text { Safety problems; need multiple injections; } \\
\text { unable to deal with mutant viruses }\end{array}$ & {$[59-64]$} \\
\hline VLP-based vaccines & $\begin{array}{l}\text { Noninfectious and could induce robust } \\
\text { antibodies; multiple choices of } \\
\text { expression systems }\end{array}$ & $\begin{array}{l}\text { Application for clinical use needs } \\
\text { further studies }\end{array}$ & {$[69-71]$} \\
\hline mRNA-based vaccines & $\begin{array}{c}\text { Rapid and flexible production; could induce } \\
\text { potent humoral and cellular } \\
\text { immune responses }\end{array}$ & $\begin{array}{l}\text { Need cold-chain storage facilities; new } \\
\text { technology, lack of historical accumulation }\end{array}$ & {$[72-74]$} \\
\hline
\end{tabular}




\section{Animal Models as Tools to Assist in the Development of Zika Vaccines}

To develop vaccines against ZIKV infection, establishment and development of specific animal models is critically important. Animal models can be developed in a number of ways, using the effects of host genetic status and immune function upon ZIKV infection [43]. Until now, scientists around the world have established murine and NHP models to study the infection mechanisms of ZIKV on the central nervous system, to test the immunogenicity of the vaccine candidates, and to assess their protective efficacy against viral infection $[23,44,63,77]$, as well as deepen our understanding of the causes of microcephaly, which, in turn, has contributed to our understanding of ZIKV and the protective immunity of hosts. The NHP model is useful to derive correlates of protection for vaccine studies, but it does not recapitulate all the clinical signs observed in humans [78]. AG129 mice, which lack both IFN- $\alpha / \beta$ and $-\gamma$ receptors, but elicit B-cell and T-cell responses to infection, support ZIKV replication and high virus load in organs exhibiting severe disease symptoms with progression to mortality $[79,80]$. As type I interferon signaling in both B- and CD4 ${ }^{+}$ T-cells is required for optimal antibody response to virus infection, vaccine studies in this mouse model do not provide a full measure of immune correlates of protection [78,81]. Nevertheless, it is an effective animal model to study vaccine efficacy against viremia, disease pathogenesis, and mortality.

\section{Conclusions}

Currently, more efforts are needed to prevent and/or treat ZIKV infection. The development of a safe and efficacious ZIKV vaccine remains a global health priority. Vaccine development and use on a large scale to prevent pandemics involve several factors such as mass production of vaccine, adjuvant selection, establishment of optimal animal models for preclinical studies, validation of safety and efficacy in animal models and clinical trials in different parts of the world using a large cohort of patients, immunization strategies, storage conditions, as well as manufacturing and production costs. Novel proposals for multi-epitope vaccines, as well as the discovery of new adjuvant formulations and delivery systems that could enhance and/or modulate immune responses, may help pave the way for development of successful vaccine candidates.

Author Contributions: N.Z., S.J. and K.S.N. conceived the idea and modified the manuscript; K.Z., C.L., W.S. and X.H. drafted the manuscript. All authors have read and agreed to the published version of the manuscript.

Funding: This research received no external funding.

Institutional Review Board Statement: Not applicable.

Informed Consent Statement: Not applicable.

Data Availability Statement: Not applicable.

Acknowledgments: Naru Zhang would like to thank Zhejiang University City College and Hangzhou Science and Technology Bureau for providing her with the startup grants (J-202106). Kutty Selva Nandakumar is grateful to Southern Medical University for providing him with the intramural grants (Grant numbers C1034211 and C1051004).

Conflicts of Interest: All authors declare no conflict of interest.

\section{References}

1. Lin, H.H.; Yip, B.S.; Huang, L.M.; Wu, S.C. Zika virus structural biology and progress in vaccine development. Biotechnol. Adv. 2018, 36, 47-53. [CrossRef]

2. Fontes-Garfias, C.R.; Shan, C.; Luo, H.; Muruato, A.E.; Medeiros, D.B.A.; Mays, E.; Xie, X.; Zou, J.; Roundy, C.M.; Wakamiya, M.; et al. Functional analysis of glycosylation of Zika virus envelope protein. Cell Rep. 2017, 21, 1180-1190. [CrossRef]

3. Song, B.H.; Yun, S.I.; Woolley, M.; Lee, Y.M. Zika virus: History, epidemiology, transmission, and clinical presentation. J. Neuroimmunol. 2017, 308, 50-64. [CrossRef]

4. Pang, W.; Lin, Y.L.; Xin, R.; Chen, X.X.; Lu, Y.; Zheng, C.B.; Yang, L.M.; Zheng, Y.T. Zika virus transmission via breast milk in suckling mice. Clin. Microbiol. Infect. 2021, 27, 469. [CrossRef] 
5. $\quad$ Regla-Nava, J.A.; Viramontes, K.M.; Vozdolska, T.; Huynh, A.T.; Villani, T.; Gardner, G.; Johnson, M.; Ferro, P.J.; Shresta, S.; Kim, K. Detection of Zika virus in mouse mammary gland and breast milk. PLoS Negl. Trop. Dis. 2019, 13, e0007080. [CrossRef] [PubMed]

6. $\quad$ Driggers, R.W.; Ho, C.Y.; Korhonen, E.M.; Kuivanen, S.; Jääskeläinen, A.J.; Smura, T.; Rosenberg, A.; Hill, D.A.; DeBiasi, R.L.; Vezina, G.; et al. Zika virus infection with prolonged maternal viremia and fetal brain abnormalities. N. Engl. J. Med. 2016, 374, 2142-2151. [CrossRef] [PubMed]

7. Noronha, L.D.; Zanluca, C.; Azevedo, M.L.; Luz, K.G.; Santos, C.N. Zika virus damages the human placental barrier and presents marked fetal neurotropism. Mem. Inst. Oswaldo Cruz 2016, 111, 287-293. [CrossRef] [PubMed]

8. Alvarado, M.G.; Schwartz, D.A. Zika virus infection in pregnancy, microcephaly, and maternal and fetal health: What we think, what we know, and what we think we know. Arch. Pathol. Lab. Med. 2017, 141, 26-32. [CrossRef] [PubMed]

9. Robbiani, D.F.; Bozzacco, L.; Keeffe, J.R.; Khouri, R.; Olsen, P.C.; Gazumyan, A.; Schaefer-Babajiw, D.; Avila-Rios, S.; Nogueira, L.; Patel, R.; et al. Recurrent potent human neutralizing antibodies to Zika virus in Brazil and Mexico. Cell 2017, 169, 597-609. [CrossRef]

10. Wen, J.; Tang, W.W.; Sheets, N.; Ellison, J.; Sette, A.; Kim, K.; Shresta, S. Identification of Zika virus epitopes reveals immunodominant and protective roles for dengue virus cross-reactive CD8+ T cells. Nat. Microbiol. 2017, 2, 17036. [CrossRef]

11. Collins, M.H.; McGowan, E.; Jadi, R.; Young, E.; Lopez, C.A.; Baric, R.S.; Lazear, H.M.; de Silva, A.M. Lack of durable crossneutralizing antibodies against Zika virus from Dengue virus infection. Emerg. Infect. Dis. 2017, 23, 773-781. [CrossRef]

12. Danko, J.R.; Beckett, C.G.; Porter, K.R. Development of dengue DNA vaccines. Vaccine 2011, 29, 7261-7266. [CrossRef]

13. Lazear, H.M.; Govero, J.; Smith, A.M.; Platt, D.J.; Fernandez, E.; Miner, J.J.; Diamond, M.S. A mouse model of Zika virus pathogenesis. Cell Host Microbe 2016, 19, 720-730. [CrossRef] [PubMed]

14. Rossi, S.L.; Tesh, R.B.; Azar, S.R.; Muruato, A.E.; Hanley, K.A.; Auguste, A.J.; Langsjoen, R.M.; Paessler, S.; Vasilakis, N.; Weaver, S.C. Characterization of a novel murine model to study Zika virus. Am. J. Trop. Med. Hyg. 2016, 94, 1362-1369. [CrossRef] [PubMed]

15. Ma, W.; Li, S.; Ma, S.; Jia, L.; Zhang, F.; Zhang, Y.; Zhang, J.; Wong, G.; Zhang, S.; Lu, X.; et al. Zika virus causes testis damage and leads to male infertility in mice. Cell 2017, 168, 542. [CrossRef] [PubMed]

16. Govero, J.; Esakky, P.; Scheaffer, S.M.; Fernandez, E.; Drury, A.; Platt, D.J.; Gorman, M.J.; Richner, J.M.; Caine, E.A.; Salazar, V.; et al. Zika virus infection damages the testes in mice. Nature 2016, 540, 438-442. [CrossRef]

17. Griffin, B.D.; Muthumani, K.; Warner, B.M.; Majer, A.; Hagan, M.; Audet, J.; Stein, D.R.; Ranadheera, C.; Racine, T.; De La Vega, M.A.; et al. DNA vaccination protects mice against Zika virus-induced damage to the testes. Nat. Commun. 2017, 8, 15743. [CrossRef] [PubMed]

18. Wang, R.; Fan, D.; Wang, L.; Song, J.; Feng, K.; Li, M.; Wang, P.; Chen, H.; An, J. Maternal immunization with a DNA vaccine candidate elicits specific passive protection against post-natal Zika virus infection in immunocompetent BALB/c mice. Vaccine 2018, 36, 3522-3532. [CrossRef] [PubMed]

19. De La Vega, M.A.; Piret, J.; Griffin, B.D.; Rhéaume, C.; Venable, M.C.; Carbonneau, J.; Couture, C.; das Neves Almeida, R.; Tremblay, R.R.; Magalhães, K.G.; et al. Zika-induced male infertility in mice is potentially reversible and preventable by deoxyribonucleic acid immunization. J. Infect. Dis. 2019, 219, 365-374. [CrossRef]

20. Gaudinski, M.R.; Houser, K.V.; Morabito, K.M.; Hu, Z.; Yamshchikov, G.; Rothwell, R.S.; Berkowitz, N.; Mendoza, F.; Saunders, J.G.; Novik, L.; et al. Safety, tolerability, and immunogenicity of two Zika virus DNA vaccine candidates in healthy adults: Randomised, open-label, phase 1 clinical trials. Lancet 2018, 391, 552-562. [CrossRef]

21. Hraber, P.; Bradfute, S.; Clarke, E.; Ye, C.; Pitard, B. Amphiphilic block copolymer delivery of a DNA vaccine against Zika virus. Vaccine 2018, 36, 6911-6917. [CrossRef]

22. Grubor-Bauk, B.; Wijesundara, D.K.; Masavuli, M.; Abbink, P.; Peterson, R.L.; Prow, N.A.; Larocca, R.A.; Mekonnen, Z.A.; Shrestha, A.; Eyre, N.S.; et al. NS1 DNA vaccination protects against Zika infection through T cell-mediated immunity in immunocompetent mice. Sci. Adv. 2019, 5, eaax2388. [CrossRef] [PubMed]

23. Dowd, K.A.; Ko, S.Y.; Morabito, K.M.; Yang, E.S.; Pelc, R.S.; DeMaso, C.R.; Castilho, L.R.; Abbink, P.; Boyd, M.; Nityanandam, R.; et al. Rapid development of a DNA vaccine for Zika virus. Science 2016, 354, 237-240. [CrossRef] [PubMed]

24. Zou, J.; Xie, X.; Luo, H.; Shan, C.; Muruato, A.E.; Weaver, S.C.; Wang, T.; Shi, P.Y. A single-dose plasmid-launched live-attenuated Zika vaccine induces protective immunity. EBioMedicine 2018, 36, 92-102. [CrossRef] [PubMed]

25. Zhang, N.; Zheng, B.J.; Lu, L.; Zhou, Y.; Jiang, S.; Du, L. Advancements in the development of subunit influenza vaccines. Microbes. Infect. 2015, 17, 123-134. [CrossRef] [PubMed]

26. To, A.; Medina, L.O.; Mfuh, K.O.; Lieberman, M.M.; Wong, T.A.S.; Namekar, M.; Nakano, E.; Lai, C.Y.; Kumar, M.; Nerurkar, V.R.; et al. Recombinant Zika virus subunits are immunogenic and efficacious in mice. MSphere 2018, 3, e00576-17. [CrossRef] [PubMed]

27. Medina, L.O.; To, A.; Lieberman, M.M.; Wong, T.A.S.; Namekar, M.; Nakano, E.; Andersen, H.; Yalley-Ogunro, J.; Greenhouse, J.; Higgs, S.; et al. A recombinant subunit based Zika virus vaccine is efficacious in non-human primates. Front. Immunol. 2018, 9 , 2464. [CrossRef]

28. Yang, M.; Dent, M.; Lai, H.; Sun, H.; Chen, Q. Immunization of Zika virus envelope protein domain III induces specific and neutralizing immune responses against Zika virus. Vaccine 2017, 35, 4287-4294. [CrossRef]

29. Zhu, X.; Li, C.; Afridi, S.K.; Zu, S.; Xu, J.W.; Quanquin, N.; Yang, H.; Cheng, G.; Xu, Z. E90 subunit vaccine protects mice from Zika virus infection and microcephaly. Acta. Neuropathol. Commun. 2018, 6, 77. [CrossRef] 
30. Han, J.F.; Qiu, Y.; Yu, J.Y.; Wang, H.J.; Deng, Y.Q.; Li, X.F.; Zhao, H.; Sun, H.X.; Qin, C.F. Immunization with truncated envelope protein of Zika virus induces protective immune response in mice. Sci. Rep. 2017, 7, 10047. [CrossRef]

31. Tai, W.; He, L.; Wang, Y.; Sun, S.; Zhao, G.; Luo, C.; Li, P.; Zhao, H.; Fremont, D.H.; Li, F.; et al. Critical neutralizing fragment of Zika virus EDIII elicits cross-neutralization and protection against divergent Zika viruses. Emerg. Microbes Infect. $2018,7,7$. [CrossRef] [PubMed]

32. Durbin, A.; Wvilder-Smith, A. An update on Zika vaccine developments. Expert Rev. Vaccines 2017, 16, 781-787. [CrossRef]

33. Collins, N.D.; Shan, C.; Nunes, B.T.D.; Widen, S.G.; Shi, P.Y.; Barrett, A.D.T.; Sarathy, V.V. Using next generation sequencing to study the genetic diversity of candidate live attenuated Zika vaccines. Vaccines 2020, 8, 161. [CrossRef]

34. Shan, C.; Muruato, A.E.; Nunes, B.T.D.; Luo, H.; Xie, X.; Medeiros, D.B.A.; Wakamiya, M.; Tesh, R.B.; Barrett, A.D.; Wang, T.; et al. A live-attenuated Zika virus vaccine candidate induces sterilizing immunity in mouse models. Nat. Med. 2017, 23, 763-767. [CrossRef] [PubMed]

35. Shan, C.; Muruato, A.E.; Jagger, B.W.; Richner, J.; Nunes, B.T.D.; Medeiros, D.B.A.; Xie, X.; Nunes, J.G.C.; Morabito, K.M.; Kong, W.P.; et al. A single-dose live-attenuated vaccine prevents Zika virus pregnancy transmission and testis damage. Nat. Commun. 2017, 8, 676. [CrossRef] [PubMed]

36. Richner, J.M.; Jagger, B.W.; Shan, C.; Fontes, C.R.; Dowd, K.A.; Cao, B.; Himansu, S.; Caine, E.A.; Nunes, B.T.D.; Medeiros, D.B.A.; et al. Vaccine mediated protection against Zika virus-induced congenital disease. Cell 2017, 170, 273-283. [CrossRef]

37. Xie, X.; Kum, D.B.; Xia, H.; Luo, H.; Shan, C.; Zou, J.; Muruato, A.E.; Medeiros, D.B.A.; Nunes, B.T.D.; Dallmeier, K.; et al. A single-dose live-attenuated Zika virus vaccine with controlled infection rounds that protects against vertical transmission. Cell Host Microbe 2018, 24, 487-499. [CrossRef]

38. Zhang, C.; Zhou, D. Adenoviral vector-based strategies against infectious disease and cancer. Hum. Vaccines Immunother. 2016, 12, 2064-2074. [CrossRef] [PubMed]

39. Bullard, B.L.; Corder, B.N.; Gorman, M.J.; Diamond, M.S.; Weaver, E.A. Efficacy of a T cell-biased adenovirus vector as a Zika virus vaccine. Sci. Rep. 2018, 8, 18017. [CrossRef]

40. Bullard, B.L.; Corder, B.N.; Gordon, D.N.; Pierson, T.C.; Weaver, E.A. Characterization of a species E adenovirus vector as a Zika virus vaccine. Sci. Rep. 2020, 10, 3613. [CrossRef]

41. Steffen, T.; Hassert, M.; Hoft, S.G.; Stone, E.T.; Zhang, J.; Geerling, E.; Grimberg, B.T.; Roberts, M.S.; Pinto, A.K.; Brien, J.D. Immunogenicity and efficacy of a recombinant human adenovirus type 5 vaccine against Zika virus. Vaccines 2020, 8, 170. [CrossRef] [PubMed]

42. Guo, Q.; Chan, J.F.W.; Poon, V.K.M.; Wu, S.; Chan, C.C.S.; Hou, L.; Yip, C.C.Y.; Ren, C.; Cai, J.P.; Zhao, M.; et al. Immunization with a novel human type 5 adenovirus-vectored vaccine expressing the premembrane and envelope proteins of Zika virus provides consistent and sterilizing protection in multiple immunocompetent and immunocompromised animal models. J. Infect. Dis. 2018, 218, 365-377. [CrossRef] [PubMed]

43. López-Camacho, C.; Abbink, P.; Larocca, R.A.; Dejnirattisai, W.; Boyd, M.; Badamchi-Zadeh, A.; Wallace, Z.R.; Doig, J.; Velazquez, R.S.; Neto, R.D.; et al. Rational Zika vaccine design via the modulation of antigen membrane anchors in chimpanzee adenoviral vectors. Nat. Commun. 2018, 9, 2441. [CrossRef] [PubMed]

44. Abbink, P.; Larocca, R.A.; De La Barrera, R.A.; Bricault, C.A.; Moseley, E.T.; Boyd, M.; Kirilova, M.; Li, Z.; Ng'ang'a, D.; Nanayakkara, O.; et al. Protective efficacy of multiple vaccine platforms against Zika virus challenge in rhesus monkeys. Science 2016, 353, 1129-1132. [CrossRef]

45. Li, A.; Yu, J.; Lu, M.; Ma, Y.; Attia, Z.; Shan, C.; Xue, M.; Liang, X.; Craig, K.; Makadiya, N.; et al. A Zika virus vaccine expressing premembrane-envelope-NS1 polyprotein. Nat. Commun. 2018, 9, 3067. [CrossRef] [PubMed]

46. Shi, X.; Hu, J.; Guo, J.; Wu, C.; Xiong, S.; Dong, C. A vesicular stomatitis virus-based vaccine carrying Zika virus capsid protein protects mice from viral infection. Virol. Sin. 2019, 34, 106-110. [CrossRef]

47. Abbink, P.; Maxfield, L.F.; Ng'ang'a, D.; Borducchi, E.N.; Iampietro, M.J.; Bricault, C.A.; Teigler, J.E.; Blackmore, S.; Parenteau, L.; Wagh, K.; et al. Construction and evaluation of novel rhesus monkey adenovirus vaccine vectors. J. Virol. 2015, 89, 1512-1522. [CrossRef]

48. Boutin, S.; Monteilhet, V.; Veron, P.; Leborgne, C.; Benveniste, O.; Montus, M.F.; Masurier, C. Prevalence of serum IgG and neutralizing factors against adeno-associated virus (AAV) types 1, 2, 5, 6, 8, and 9 in the healthy population: Implications for gene therapy using AAV vectors. Hum. Gene Ther. 2010, 21, 704-712. [CrossRef]

49. Li, C.; Narkbunnam, N.; Samulski, R.J.; Asokan, A.; Hu, G.; Jacobson, L.J.; Manco-Johnson, M.J.; Monahan, P.E. Neutralizing antibodies against adeno-associated virus examined prospectively in pediatric patients with hemophilia. Gene Ther. 2012, 19, 288-294. [CrossRef]

50. Mingozzi, F.; High, K.A. Overcoming the host immune response to adeno-associated virus gene delivery vectors: The race between clearance, tolerance, neutralization, and escape. Annu. Rev. Virol. 2017, 4, 511-534. [CrossRef]

51. Meliani, A.; Boisgerault, F.; Hardet, R.; Marmier, S.; Collaud, F.; Ronzitti, G.; Leborgne, C.; Verdera, H.C.; Sola, M.S.; Charles, S.; et al. Antigen-selective modulation of AAV immunogenicity with tolerogenic rapamycin nanoparticles enables successful vector re-administration. Nat. Commun. 2018, 9, 4098. [CrossRef]

52. von Pawel-Rammingen, U.; Johansson, B.P.; Björck, L. IdeS, a novel streptococcal cysteine proteinase with unique specificity for immunoglobulin G. EMBO J. 2002, 21, 1607-1615. [CrossRef] 
53. Wenig, K.; Chatwell, L.; von Pawel-Rammingen, U.; Björck, L.; Huber, R.; Sondermann, P. Structure of the streptococcal endopeptidase IdeS, a cysteine proteinase with strict specificity for IgG. Proc. Natl. Acad. Sci. USA 2004, 101, 17371-17376. [CrossRef]

54. Kizlik-Masson, C.; Deveuve, Q.; Zhou, Y.; Vayne, C.; Thibault, G.; McKenzie, S.E.; Pouplard, C.; Loyau, S.; Gruel, Y.; Rollin, J. Cleavage of anti-PF4/heparin IgG by a bacterial protease and potential benefit in heparin-induced thrombocytopenia. Blood 2019, 133, 2427-2435. [CrossRef]

55. Lorant, T.; Bengtsson, M.; Eich, T.; Eriksson, B.M.; Winstedt, L.; Järnum, S.; Stenberg, Y.; Robertson, A.K.; Mosén, K.; Björck, L.; et al. Safety, immunogenicity, pharmacokinetics, and efficacy of degradation of anti-HLA antibodies by IdeS (imlifidase) in chronic kidney disease patients. Am. J. Transplant. 2018, 18, 2752-2762. [CrossRef]

56. Nandakumar, K.S.; Holmdahl, R. Therapeutic cleavage of IgG: New avenues for treating inflammation. Trends Immunol. 2008, 29, 173-178. [CrossRef]

57. Leborgne, C.; Barbon, E.; Alexander, J.M.; Hanby, H.; Delignat, S.; Cohen, D.M.; Collaud, F.; Muraleetharan, S.; Lupo, D.; Silverberg, J.; et al. IgG-cleaving endopeptidase enables in vivo gene therapy in the presence of anti-AAV neutralizing antibodies. Nat. Med. 2020, 26, 1096-1101. [CrossRef]

58. Austin, A.L.; Galasso, B.; Nickens, C.; Knollmann-Ritschel, B.; Sharma, A. Inactivation of Zika virus by photoactive iodonaphthyl azide preserves immunogenic potential of the virus. Pathogens 2019, 8, 188. [CrossRef] [PubMed]

59. Baldwin, W.R.; Livengood, J.A.; Giebler, H.A.; Stovall, J.L.; Boroughs, K.L.; Sonnberg, S.; Bohning, K.J.; Dietrich, E.A.; Ong, Y.T.; Danh, H.K.; et al. Purified inactivated Zika vaccine candidates afford protection against lethal challenge in mice. Sci. Rep. 2018, 8, 16509. [CrossRef]

60. Lecouturier, V.; Bernard, M.C.; Berry, C.; Carayol, S.; Richier, E.; Boudet, F.; Heinrichs, J. Immunogenicity and protection conferred by an optimized purified inactivated Zika vaccine in mice. Vaccine 2019, 37, 2679-2686. [CrossRef]

61. Lecouturier, V.; Pavot, V.; Berry, C.; Donadieu, A.; de Montfort, A.; Boudet, F.; Rokbi, B.; Jackson, N.; Heinrichs, J. An optimized purified inactivated Zika vaccine provides sustained immunogenicity and protection in cynomolgus macaques. NPJ Vaccines 2020, 5, 19. [CrossRef]

62. Young, G.; Bohning, K.J.; Zahralban-Steele, M.; Hather, G.; Tadepalli, S.; Mickey, K.; Godin, C.S.; Sanisetty, S.; Sonnberg, S.; Patel, H.K.; et al. Complete protection in macaques conferred by purified inactivated Zika vaccine: Defining a correlate of protection. Sci. Rep. 2020, 10, 3488. [CrossRef]

63. Abbink, P.; Larocca, R.A.; Visitsunthorn, K.; Boyd, M.; De La Barrera, R.A.; Gromowski, G.D.; Kirilova, M.; Peterson, R.; Li, Z.; Nanayakkara, O.; et al. Durability and correlates of vaccine protection against Zika virus in rhesus monkeys. Sci. Transl. Med. 2017, 9, eaao4163. [CrossRef]

64. Stephenson, K.E.; Tan, C.S.; Walsh, S.R.; Hale, A.; Ansel, J.L.; Kanjilal, D.G.; Jaegle, K.; Peter, L.; Borducchi, E.N.; Nkolola, J.P.; et al. Safety and immunogenicity of a Zika purified inactivated virus vaccine given via standard, accelerated, or shortened schedules: A single-centre, double-blind, sequential-group, randomised, placebo-controlled, phase 1 trial. Lancet Infect. Dis. 2020, 20, 1061-1070. [CrossRef]

65. Dussupt, V.; Sankhala, R.S.; Gromowski, G.D.; Donofrio, G.; De La Barrera, R.A.; Larocca, R.A.; Zaky, W.; Mendez-Rivera, L.; Choe, M.; Davidson, E.; et al. Potent Zika and dengue cross-neutralizing antibodies induced by Zika vaccination in a dengue-experienced donor. Nat. Med. 2020, 26, 228-235. [CrossRef]

66. Yang, Y.; Shan, C.; Zou, J.; Muruato, A.E.; Bruno, D.N.; de Almeida Medeiros Daniele, B.; Vasconcelos, P.F.C.; Rossi, S.L.; Weaver, S.C.; Xie, X.; et al. A cDNA clone-launched platform for high-yield production of inactivated Zika vaccine. EBioMedicine 2017, 17, 145-156. [CrossRef] [PubMed]

67. Boigard, H.; Alimova, A.; Martin, G.R.; Katz, A.; Gottlieb, P.; Galarza, J.M. Zika virus-like particle (VLP) based vaccine. PLoS Negl. Trop. Dis. 2017, 11, e0005608. [CrossRef]

68. Garg, H.; Sedano, M.; Plata, G.; Punke, E.B.; Joshi, A. Development of virus-like-particle vaccine and reporter assay for Zika virus. J. Virol. 2017, 91, e00834-17. [CrossRef]

69. Espinosa, D.; Mendy, J.; Manayani, D.; Vang, L.; Wang, C.; Richard, T.; Guenther, B.; Aruri, J.; Avanzini, J.; Garduno, F.; et al. Passive transfer of immune sera induced by a Zika virus-like particle vaccine protects AG129 mice against lethal Zika virus challenge. EBioMedicine 2018, 27, 61-70. [CrossRef]

70. Dai, S.; Zhang, T.; Zhang, Y.; Wang, H.; Deng, F. Zika virus baculovirus-expressed virus-like particles induce neutralizing antibodies in mice. Virol. Sin. 2018, 33, 213-226. [CrossRef]

71. Yang, M.; Lai, H.; Sun, H.; Chen, Q. Virus-like particles that display Zika virus envelope protein domain III induce potent neutralizing immune responses in mice. Sci. Rep. 2017, 7, 7679. [CrossRef]

72. Zhong, Z.; Portela Catani, J.P.; Mc Cafferty, S.; Couck, L.; Van Den Broeck, W.; Gorlé, N.; Vandenbroucke, R.E.; Devriendt, B.; Ulbert, S.; Cnops, L.; et al. Immunogenicity and protection efficacy of a naked self-replicating mRNA-based Zika virus vaccine. Vaccines 2019, 7, 96. [CrossRef] [PubMed]

73. Richner, J.M.; Himansu, S.; Dowd, K.A.; Butler, S.L.; Salazar, V.; Fox, J.M.; Julander, J.G.; Tang, W.W.; Shresta, S.; Pierson, T.C.; et al. Modified mRNA vaccines protect against Zika virus infection. Cell 2017, 169, 176. [CrossRef]

74. Pardi, N.; Hogan, M.J.; Pelc, R.S.; Muramatsu, H.; Andersen, H.; DeMaso, C.R.; Dowd, K.A.; Sutherland, L.L.; Scearce, R.M.; Parks, R.; et al. Zika virus protection by a single low-dose nucleoside-modified mRNA vaccination. Nature 2017, 543, 248-251. [CrossRef] 
75. Xie, X.; Yang, Y.; Muruato, A.E.; Zou, J.; Shan, C.; Nunes, B.T.; Medeiros, D.B.; Vasconcelos, P.F.; Weaver, S.C.; Rossi, S.L.; et al. Understanding Zika virus stability and developing a chimeric vaccine through functional analysis. MBio 2017, 8, e02134-16. [CrossRef]

76. Nandy, A.; Basak, S.C. A brief review of computer-assisted approaches to rational design of peptide vaccines. Int. J. Mol. Sci. 2016, 17, 666. [CrossRef]

77. Rayner, J.O.; Kalkeri, R.; Goebel, S.; Cai, Z.; Green, B.; Lin, S.; Snyder, B.; Hageli, K.; Walters, K.B.; Koide, F. Comparative pathogenesis of Asian and African-lineage Zika virus in Indian rhesus macaque's and development of a non-human primate model suitable for the evaluation of new drugs and vaccines. Viruses 2018, 10, 229. [CrossRef]

78. Sumathy, K.; Kulkarni, B.; Gondu, R.K.; Ponnuru, S.K.; Bonguram, N.; Eligeti, R.; Gadiyaram, S.; Praturi, U.; Chougule, B.; Karunakaran, L.; et al. Protective efficacy of Zika vaccine in AG129 mouse model. Sci. Rep. 2017, 7, 46375. [CrossRef]

79. Zompi, S.; Santich, B.H.; Beatty, P.R.; Harris, E. Protection from secondary dengue virus infection in a mouse model reveals the role of serotype cross-reactive B and T cells. J. Immunol. 2012, 188, 404-416. [CrossRef]

80. Aliota, M.T.; Caine, E.A.; Walker, E.C.; Larkin, K.E.; Camacho, E.; Osorio, J.E. Characterization of lethal Zika virus infection in AG129 Mice. PLoS. Negl. Trop. Dis. 2016, 10, e0004682. [CrossRef]

81. Zhu, J.; Huang, X.; Yang, Y. Type I IFN signaling on both B and CD4 T cells is required for protective antibody response to adenovirus. J. Immunol. 2007, 178, 3505-3510. [CrossRef] [PubMed] 